\title{
第三回ペルシア語世界研究学会大会参加報告
}

\section{Report on the Third ASPS Biennial Convention in Tiflis, "Society, History and Culture in the Persianate World"}

\author{
前田君 江 \\ MAEDA Kimie \\ 前田 弘毅 \\ MAEDA Hirotake
}

2007年 6 月 8 日から 11 日まで, グルジア国トビリシにおいて, ペルシア語世界研究学会 Association for the Studies of Persianate Societies 第三回大会「ペルシア語世界におけ る社会, 歴史と文化」Society, History and Culture in the Persianate World が開催さ (1)

れた(上記学会の他, トビリシ大学と東洋学研究所の共催)。本学会会員では前田君江, 前田弘毅両名が参加し，それぞれ報告を行った。日本からの参加者は初めてとのことも あり,ここに若干の印象を記したい。

上記学会はアメリカのイラン研究者が中心となり近年設立された若い学会である。第 一回の大会は, 2002年, ドゥシャンべ (タジキスタン) で開催され, 続いて 2004 年にイェ レヴァン（アルメニア）で第二回大会が行われた。学会名と過去の大会開催地が示すよ うに，「イラン一国史」研究を超えた歴史的なペルシア世界研究を追究している。なお， 今大会は，当初，1月にラホールで行われる予定であったが，資金不足や参加予定者の ビザの問題などから中止となり，急遽，グルジアで開催されることになったという。

第三回の開催地となったグルジア国トビリシは，昨年来顕著に悪化した対ロシア関係 の余波もあり，交通の便等の制約も多く，最終的に参加を断念する者も少なくなかった。 当初, 76本の報告が予定されていたが, 実際に発表が行われたのは六割程度であった。 それでも, 学会会長でイラン宗教史のアルジョマンド教授 (Saïd Amir Arjomand, SUNY College at Stony Brook), イラン現代政治のシェハービー教授 (Houchang E. Chehabi, Boston University) らをはじめとするアメリカ在住の著名なイラン研究者のほ か, イランからも, 2007年 1 月に大阪外国語大学主催の国際セミナーにも来日したテへラ

* 東京大学・東京外国語大学非常勤講師

Part-time Lecturer, The University of Tokyo and Tokyo University of Foreign Studies

** 北海道大学スラブ研究センター講師

Lecturer, Slavic Research Center, Hokkaido University 
ン大学言語学科のサーデギー教授（Ali Ashraf Sadeqi）や, 地理学製図研究所のサハー ブ教授（Mohammad Reza Sahab）などが参加した。

こうした参加者の顔ぶれからも分かるように，同学会はアメリカに拠点を置いてはい るが, 実はイランからの参加者がアメリカのそれを上回るなど，予想外に「イラン色」 が濃かったことが指摘できる。大会報告や質疑応答では, ペルシア語が, 英語を凌ぐ共 通語となっていた。さらに，前回開催地でグルジアの隣国であるアルメニアから多数の 研究者が参加し, ホスト国グルジアやパキスタン, タジキスタンといった「歴史的ペル シア世界周縁」からの参加者が，それぞれお国柄やお国訛りのペルシア語を披露しなが ら強い個性を発揮して大会を彩った。

さて, 個別発表を紹介すると, 学会事務局を務め今大会の運営委員長でもあったボル ジヤーン助教授 (Habib Borjiyan, Hofstra University) によるイラン北西部のイラン 系言語諸方言に関する報告や，ジョネイディ=ジャアファリー氏 (Mahmud JoneydiJa'fari）によるカーシャーン地方の方言についての報告をはじめとし, イラン, アルメニ アの研究者による言語学分野での報告が多く, 活発な質疑応答が行われた。また, 夕ジ キスタンのラフマーニー教授（Ravshan Rahmoni）による民話収集に関する報告や，口 シアの研究者ボイコ氏 (Vladimir Boyko, Barnaul State Pedagogical University) によ るアフガニスタンの政治家ハリール・アッラー・ハリーリーに関する報告, テヘラン大 学で音楽史を講ずるプールジャヴァーディー氏（Amir Hosein Pourjavady）によるサ ファヴィー朝期のグルジア出身宮廷音楽家アミール・ハーン・ゴルジーに関する報告な どが目立った。

歴史に関する報告でも，「周縁」からの視点による「ペルシア世界」の相対化の作業に 関連する興味深い報告が見られた。例えば，ホスト国グルジア人学者によるものでは， 19世紀におけるトビリシのイラン人社会を扱ったアレクシゼ氏 (Marina Alexidze, Tbilisi State University and Institute of Oriental Studies）による報告や，やはり19世紀に おけるイェレヴァンの宮殿改修を手がかりに帝政ロシアにおけるオリエント・ブームを 解析したコショリゼ氏 (Irene Koshoridze, Georgian National Museum) の報告, ゴチェ レイシュヴィリ (Iago Gocheleishvili, Cornell University)によるイラン立憲革命におけ るグルジア人革命家の肖像を具体的に追究した報告が特に充実していた。

文学では，ロブジャニゼ氏（Giorgi Lobzhanidze, I. Javakhishvili Tbilisi State University）が，イランの現代詩人ソフラーブ・セペフリーの詩に現れる「旅」のイメージ について興味深い報告を行った。イランの先行研究では，セペフリーの詩的世界につい て, 東洋哲学と仏教思想の影響が強調されるが, ロブジャニゼ氏はイスラーム神秘主義 の観点から分析を行い, ポーランドのペルシア文学・イラン研究者スムルジンスキー氏 
と筆者（前田君江）がこれに大いに賛同した。さらに，コロンビア大学で編纂されてい るイラン大百科のホームページにもその顔がみえるイラン研究の世界的な大家で, ソ連 崩壞後に駐イラン・グルジア大使を 10 年間務めたジェムシド・ギウナシュヴィリ博士は, 高齢を押して自ら報告を行い，巧みなペルシア語とユーモアを交えた話ぶりで聴衆を魅 了した。

ちなみに前田君江は，アフマド・シャームルーの非韻律詩のリズム分析に関する報告 (Ahmad Shamlu and his Poetics of Non-Verse Poems) を，また，前田弘毅はシャー・ アッバースに対する反乱をグルジアで主導したギオルギ・サアカゼに関する発表 (Martqopi's Revolt and Safavid Historiography）をそれぞれ行った。

以上のように，「ペルシア文化」と一括りにすることができない多彩な文化接触の諸相 が取り上げられ，極めて興味深い大会であった。短い準備期間にもかかわらず，こうし た大会が可能となった背景のは，グルジアおよび旧ソ連諸国におけるイラン学の蓄積に よるところが大きい。また，政治的立場においても，グルジアは現在独特の位置を占め ている。旧ソ連から独立後, 一貫して親欧米路線を歩み, 2005年にはブッシュ米大統領が 訪問したことでも話題になったグルジアであるが，イランと友好関係を維持し，サアカ シュヴィリ大統領も大統領就任後間もない2004年夏にイランを訪問していることはあま り知られていない。しかし，帝政ロシア時代から中東への玄関口として栄えたトビリシ を首都とするグルジアは, 現在も，こうした世界秩序の結節点としてユニークな位置を 占めているのである。

ちなみに，本大会と直接は関係していないが，上記のロブジャニゼ氏は，グルジア語 で事実上初めてとなるコーランの全訳書（大判で翻訳が300ページ，注勫が300ページ以 上）を本年 5 月に出版したばかりであり，学会終了後に出版記念会が行われた。彼は, 当時の駐イラン・グルジア大使を務めていたギウナシュヴィリ氏の後押しで外国人・異 教徒としては異例のテヘラン大学神学部に留学した。アラビア語とペルシア語を完璧に 操り，なによりもコーランに精通する若干32歳のロブジャニゼのこの偉業に，「周縁」グ ルジアにおけるイラン研究の凄みが凝縮されている。筆者（前田弘毅）にとっても，初 めてグルジアを訪れた際に何かと世話を焼いてくれた 20 代前半からの近しい友人であり， 氏のコーラン翻訳にかける強い思いをその当時から知っているだけに, 貴重な場に居合 わせることができたのは幸いであった。

さて, 上記大会最終日前夜にはレセプションが開かれ, 歌と踊りで世界に名高いホス 卜国の雾囲気もあってか，世界的に著名な学者たちの気さくで陽気な一面を見ることも できた。こうした直接の交流は国際学会の醍醐味の一つである。ソ連崩壊後, 困難な社 会状況の中で, それまでの貴重な研究遺産を護りながら, 細々と学究の灯火を点してい 
る旧ソ連圏研究者は, 心温まるホスピタリティを発揮してくれた。手作りの学会は, 規 模こそ西欧の学会に劣りこそすれ，研究者個々人と親交を深めることのできる研究交流 に最適の場であったといえる。現地における学会組織者を務めた東洋学研究所のギオル ギ・サニキゼ所長 (2005年に来日, 北海道大学スラブ研究センターに外国人研究員として 在職）に心から御礼を申し上げたい。その一方で, 参加予定者が政治的な事情でイラン 政府に拘束され, 参加不可能となるなど, イラン研究の難しさを実感させる局面が随所 に見られた点も指摘する必要があろう。

なお, この学会の目指す方向, すなわち, 既存国家を超えた「地域」組み換えによる 新たな研究パラダイム模索の動きは, 実はわが国でもさかんになりつつある。東京外国 語大学や大阪大学は, 積極的にアフガニスタンやイランとの交流を進めている。北海道 大学スラブ研究センターでも, COEプログラム『スラブ・ユーラシア学の構築』(2003年 度〜) の中で, ペルシア語文化圈に関する研究会が開催された。また, 今年度からは東京 外国語大学アジア・アフリカ言語文化研究所でも「ペルシア語文化圈の歴史と社会」プ ロジェクトが始動した。今後, こうした成果を共有するべく, 海外の研究者との一層の 提携・交流が望まれよう。

ペルシア語世界研究学会の次回大会は, 本来第三回学会の開催地であったラホールで 予定されている。本学会会員からの積極的な参加も望まれる。

注

（1）学会名中の“Persinate Societies”は「「ペルシア語共同体（コミュニティー)」を 指すものと思われる。この場合の「ペルシア語」は無論, イランのペルシア語のみな らず, ダリ一語, タジク語, その他古代から現代までのイラン諸語を含めたものであ る。また,「ペルシア語共同体（コミュニティー）とは, 歴史的なペルシア語文化圈 や, 現代におけるペルシア語圏, さらには, 北欧・北米など中東地域以外のペルシア 語コミュニティーをも包含するものであると考えられる。また，大会テーマ中の “Persianate World”「ペルシア語世界」も, ほぼ同様の意図で用いられていると推測で きる。

以上を踏まえて, 学会名を「ペルシア語共同体研究学会」と訳すこともできるが, 日本語の「共同体 (コミュニティー)」の語からは, 此較的小さな集団が想起される。 そのため, 本稿では, “Persianate Societies”にも「ペルシア語世界」の訳語を宛て, 学会名を「ペルシア語世界研究学会」と訳した。

（2）本稿での大会参加者氏名のローマ字表記は，いずれも，大会プログラムに拠った。 